\title{
STRATEGY OF ARGUMENT IMPACT IN AMERICAN POLITICAL ADVERTISEMENT
}

\author{
Chulanova G. V., Candidate of Philology, Associate Professor \\ ORCID ID: https://orcid.org/0000-0001-9961-0308 \\ Syzonenko M.I., Student \\ Sumy State University \\ 2, Rymskogo-Korsakova St., Sumy, 40007, Ukraine \\ Email: syzonenko9711@gmail.com,g.chulanova@gf.sumdu.edu.ua
}

The article considers the strategy as a clearly defined plan aimed to achieve a communicative goal in the political advertisement. The basic elements of the argumentation and impact, their functions, as well as the importance of the communication for the participants have been thoroughly studied. In addition, as a result of the work of mwany researchers who also studied this topic, the notion of "strategy", "influence" and "argumentation" has been clearly specified. In the course of the investigation various bright pictures, touching stories and motivating speeches that create a great effect on the viewer have been analyzed. The advertisement is defined as an effective means of argument impact on the society in the political sphere of life. Based on the material of the reviewed American political advertisement, the main language tools that politicians use to achieve a specific goal are identified. From a number of different classifications, one was singled out for which selected examples of American advertising were actually investigated. An important part of the work was also to highlight the prospects for further researches within the chosen topic in linguistics and other sciences. At the own initiative, prospects for a more detailed study of the impact of advertisement were noted, whose effect is not less in other areas of society.

Key words: strategy, argumentation, impact, political advertisement.

https://doi.org/10.21272/Ftrk.2018.10(4)-10

Introduction. In the era of technology, media has become particularly important for the individual as well as for the mankind. Being the middle point of the communication process between the addresser and the addressee, the media performs a number of functions.

The election campaign of any country involves a crazy stream of political advertisement, in which strategies and tactics of impact on voters are used in the most elaborate way. An important part of the advertisement is argumentation. Based on wellformed facts, it can effectively affect the recipients. In this article, particular attention is paid to the impact function of the advertisement on participants during the communication process. Advertisement s a means of impact on society is considered within the American political discourse.

The strategy of impact influence in various discourses, including political one, has been studied by such well-known researchers as: Skovorodnikov A. P, Issers O. S., Moskalenko V.V., Holovatyi M. F., Pocheptsov G. G., Borysova I. N. and others. In their works, they managed not only to distinguish the notion of "strategy", "impact" and "argumentation", but also to classify them in various groups, as well as to study their usage in other spheres of life.

The subject area is political discourse, in which strategies and tactics of influence on society are considered.

The specific topic of the study includes impact strategies, as well as the various means, facts and details by which they are implemented.

The research material of the study is American political advertisement within the process of presidential election.

The objectives of the research is to identify the impact strategies and tactics used in political advertisement. It is also important to study the arguments used by politicians in

(C) Chulanova G. V., Syzonenko M.I., 2018 
their speeches to voters and to create own understanding of the strategy of argument impact on society.

Based on the objective, we can imply on tasks of the research: 1) a thorough research of the concepts related to the strategy of the argument impact; 2) review of American political advertisement; 3) research of linguistic means used in political advertisement.

The research methodology includes the following research methods: analysis, comparison and observation.

The relevance of the study is due to the fact that policy and means of impact on society are always interesting topics for researchers to study in other scientific fields as well. Especially important are lexical, phonetic and grammatical tools that help to create the desired effect.

The practical value of the results and conclusions gives more accurate and realistic view of the available impact strategies and the ways of their implementation. Selected language means that visualize the impact on society can be a material for the further research in the field of linguistics. Acquired knowledge of tactics and strategies can be actively used in any other sphere of society as well.

Results of the research.

By the origin, the term "strategy" is a military term, which means the art of studying the consistent patterns, as well as the nature of the war. Important part is also investigating the theoretical basis of the preparation and carrying out of wide-ranging military operations, aimed order to carry out strategic tasks. [1, p. 5].

The Cambridge Dictionary defines the term "strategy" as a long-term or short-term detailed plan, aimed to achieve a specific goal, or learn the skills, that are necessary to implement certain plans in the military, political, economic spheres, business, sports, industry, etc. [2].

It should be mentioned that a lot of scientists define the term "strategy" in their own way. But, considering all the definitions, it can be noted that the strategy is the result of conscious planning of the sequence of actions. This is the way of achieving the goal by the communicator, as a participant of the communicative process.

Since the strategy is considered a process of finding alternative actions for achieving a certain result, it has its own characteristic features and elements. The first element of the strategy is the "target guidance" used by the addresser in order to motivate the addressee to do some actions, to evoke certain feelings and emotions, to inspire his point of view, etc. The next important component is the formulation of abstracts, that serve as the so-called responses to speakers questions. Quite important is the argumentation, comprehensive speaker knowledge, as well as some experience [3, p. 14].

Argumentation is the procedure of mentioning of certain facts or so-called arguments by one party in order to change the point of view, position or beliefs of the other party. First of all, the argumentation is always addressed to the person's mind, that is capable of accepting it and after thinking, agree, or vice versa, to contradict it [4, p. 3].

Since the attention is focused on the impact of strategies and tactics on the recipients of advertisement messages, the notion of these terms has been investigated as well. The psychological impact - the impact of one individual on the mental state, thoughts, actions, emotions of another individual through the verbal or nonverbal psychological means. For the psychological impact, it is peculiar that the recipient has the ability to contradict it. That means to response to the initiator's impact with the same psychological means [ 5, p. 20].

The three main elements of impact are: mental set, behavior and cognition. In order to achieve the goal, which is to change thoughts or beliefs of the addressee, the speaker gives the mind set in his speech or during direct communication. Such a statement is always enforced by his behavior, which in its turn confirms its correctness and effectiveness [6, p. 35].

The next element of the strategy is tactic. This term can be defined as a specific linguistic course or action used by the speaker in a communication process for implementation of the linguistic strategy. It is important to notice that the tools for 
implementing a particular strategy can have the form of diverse tactics. Consequently, the effectiveness of the language strategy can be evaluated considering the achieving of the greatest number of goals [7, p. 101].

In the process of research, three strategies for influencing society have been identified:

1. Lowering strategy (tactics of accusation, including impersonal, exposure, image).

2. Rising strategy (tactics of presentation, exclusion of criticism, self-justification).

3. Theatrical strategy (tactics of motivation, differentiation, forecasting, provocation, warning) [8, p. 68].

Political advertising is one of numerous spheres of advertising that has an impact on the society. Any advertisement is produced or displayed in order to motivate people to take action for achieving some results. Considering that the advertisement is aimed to have an impact on the viewer's consciousness, an important condition is the minimum interval of showing and the fastest possible response. There is a large number of definitions of the term "advertising". A. Deyayan, for example, defines advertisement as an appeal through the mass media or any other means of communication, the purpose of which is to campaign in the favor of a certain product, organization, political party, candidate, etc. Moreover, the linguist notes that the appeal is impersonal, since it is directed not to any particular person, but to a group of people or even the whole society; one-directional, as far as it is directed to the recipient without reciprocal action; and not free of charge, because for any appeal or message the advertiser is forced to pay [9, p. 4].

The purpose of an advertisement is to activate one or another type of political behavior, that is, to encourage the participation in certain political processes, in particular the delegation of representatives of the political party, etc.

Political advertisement also performs the following functions:

1. Informational, as it provides the viewer with the certain information, introduces facts, events, etc.

2. Communicative, since contact is established between representatives of the authorities and the public through means of reporting an advertising message [10, p. 12].

3 . Target, because the advertisement is directed to a certain category or group of people for more effective impact and obtaining the corresponding result.

4. Ideological or social-orienting, as far as advertising messages advocate a certain topic, sphere of life or its direction.

Apart from the goals and functions, any advertisement has its subject and object. Therefore, the subject of an advertisement is the advertiser himself, the political party or its representative. The object is a single individual, or a group of them, who have the task to respond to one or another political advertisement [11, p. 13].

During the conducted investigation, 150 political commercials of the American election campaign were studied. Therefore, considering the example of these advertisements the use of impact strategies on voters, language tools and various tactics is analyzed.

One of the most remarkable examples of the lowering strategy is Donald Trump's agitational advertisement, in which one can identify the following tactics and means by which it has been implemented:

"In Hillary Clinton's America the middle class gets crushed, spending goes up, taxes go up, hundreds of thousands of jobs disappear. It's more of the same, but worse. In Donald Trump's America working families get tax relief, millions of new jobs are created, wages go up, small businesses thrive, The American Dream is achievable. Change that makes America great again. Donald Trump for President. Make America great again!'” [12].

In the example given above the author used verbs with a negative shade of meaning: "gets crushed", "disappear", that is, attention is drawn specifically to the disadvantages of Hillary Clinton's policy and the consequences of such actions. In contrast, the writer applies following lexical units that have a positive shade of meaning in order to make Trump's policy a step to a new life: "thrive", "achievable", "go up", "created." In order to strengthen the impact on the American society, the symbolic phrase "The American Dream"is used as 
well. Moreover, it is known to every inhabitant of America and evokes positive associations at the subconscious level.

Another example is Trump's speech used in Hillary Klinton's political advertisement:

"'I would bomb the shit out of them', 'I would just bomb those suckers', 'I'd blow every single inch', 'There would be nothing left'. Nobody wants to hear that about American President. Why do make it than, why do we make it? You have to take out their families when you get these terrorists; you have to take out their families. 'What do you have to lose? By trying something new like Trump. What do you have to lose?' We have everything to lose. No trump. No red button" [13].

In order to expose Trump's destruction actions, the politician used such lexical units, as: "bomb", "suckers", "blow", "nothing left". In addition, responding to Trump's question "What do you have to lose?", Clinton emphasizes not only on his cruelty, but also irresponsibility and indifference. Thus, the formation of a negative impression of her opponent and a good attitude toward Hillary Clinton herself - as a person who really aims at solving large-scale problems has been achieved.

One of the tragic examples based on the real events is the story of a Muslim soldier, that is told by his father. This story is a direct accusation of Trump's policy and his actions that led to the death:

"In 2004, my son was stationed in Iraq. He saw a suiside bomber approaching his camp. My son moved forward to stop the bomber when the bomb exploded. He saved everyone in his unit. Only one American soldier died, my son was Captain Humayun Khan. He was 27 years old, and he was a Muslim American. I want to ask Mr. Trump, would my son have a place in your America. Stronger together. H. Clinton" [14].

The key notion of this advertising message is the "Muslim American", who raises the topic of the racism in America. So, with this story Hillary Clinton shows that not all Muslims are terrorists, and, moreover, some of them have saved many lives: "He saved everyone in his unit." The lexical unit "place in your America" emphasizes the fact that Trump's policy is unfair, if his country lacks place for this or that person. But, despite such sad events, the politician proposes to stick together and make the life better. This is illustrated by the phrase "Stronger together", which can be attributed to the means of implementing the tactics of co-operation between the politician and the society.

The next interesting strategy in the study is the rising strategy, which also includes a variety of tactics, including the tactics of the so-called presentation. It has been artistically used in another political advertisement by Hillary Clinton. In her appeal to American society, the tactics of the so-called presentation itself have been used as part of the rising strategy.

"How do we measure greatness in America, the high of our skyscrapers, the sire of our bank accounts? No it's measured by what we do for our children, the values we pass on. I've spent my life fighting for kids and families and it'll be my mission to build a country, where our children can rise as high as their dreams and hard work take them. That means good schools for every child in every zip code; college that leads to opportunities not debt; and economy, where very young American can find a job that lets them start a family of their own. We face big challenges, but we can solve them the same way families do working together, respecting one another and never giving up. I want our success to be measured by their" [15].

As one can see, the message was initially addressed in the form of a question to the recipients in order to attract their attention: "How do we measure greatness in America?". The question is followed by a story in the first person, which, with the help of arguments, proves the truth of the speaker's actions: "I've spent my life fighting for". The next one is the actual presentation of the plans, as well as the results that Hillary Clinton intends to achieve, and is confirmed by such lexical units, as: "good schools for every child", "opportunities for", "never giving up". Such an advertising campaign, that clearly sets out the plans and tasks that should be carried out, promptly motivate the recipients to action.

Another example is Ronald Reagan's advertisement: 
"It's morning again in America. Today more man and women will go to work than ever before in our country's history. Interest rates are at about half of the record hights of 1980. Nearly 2000 families today will buy new homes. More than at any time in the past four years. This afternoon 6500 young man and woman will be married with inflation at least that a half of what it was just four years ago. They can look forward with confidence to the future. It's morning again in America and under the leadership of President Reagan our country is prouder and stronger and better. Why should we ever want to return to where we were less than four short years ago" [16].

In the first part of the message, again, the person of the politician himself is not defined. Lexical units that are used there, symbolize society, people, but not a specific person: "man and women", "families". In addition the pronoun "them" is used, as well as the name of the country "America", which means the whole country and its citizens. Thus, the author of the advertisement summarizes the facts of improving the life standards in the country using the adverb "more", the noun "future", which draws attention to the best changes in the future, only within the Ronald Reagan's policy. In contrast, such lexical units, as: "years ago" denotes past and not happy period of life. Additionally, one can also find adjectives of higher degree: "prouder", "stronger", "better". Thus, with the help of various not only lexical but also grammatical means, such as the degree of comparison of adjectives, and various meanings of words, political advertisement can have an effect on society.

Somewhat different tactic in his political advertising was taken by Ben Carson, who called the tactics of an uncertain presentation itself:

"These hands translate life into lyrics. These hands transport 6000 galoons of milk per day. These hands wait tables to get by. These hands are praising six boys. These hands fixed things for 30 years. These hands translate film into Mandarin. These hands teach self - control. These hands have repaired 5237 vehicles. These hands lived through the depression. These hands fought against prejudice. These hands help hurting people. These hands are working toward citizenship. These hands are working to heal America. I am Ben Carson and I approve this message" [17].

With the frequent use of the lexical unit "these hands", the emphasis is placed on its polysemy. Thus, in the sentence "These hands translate life into lyrics", this lexical unit has the meaning of the certain person who writes songs; "These hands are praising six boys" parents; "These hands help hurting people" - in general, terrorists or murderers. But then there is another change in shade of meaning, and the lexical unit already represents the politician and his party, as in the sentence, for example: "These hands are working to heal America." Thus, without naming one's own person or without mentioning the name of the party, the politician still attracts attention and asserts in the determination of his actions and the effectiveness of his own policies.

Another influential strategy in political advertisement is the theatrical strategy. One of Hillary Clinton's speeches is an example of implementing the strategy outlined above using tactics of motivation.

"I'm voting for respect. I'm voting for courage. I'm voting for equality. I'm voting for community. I'm voting for fairness. Get ready, cause I've had enough. I'm voting for higher wages. I'm voting for debt relief. I'm voting for this baby. I'm voting against hate. I'm voting for the planet. I'm voting for our future. I'm voting for a President. I a, Hilary Clinton and I approve this message" [18].

Another effective tactic is present in Barack Obama's speech to the American society and called the tactics of promises. In his speech to the people he describes his plan of action, committing himself to fulfill it during his presidency.

"There is no quit in America, and you are seeing that right now. Over 5 millions new jobs. Exports to 41 percent. Home values: rising. Our auto industry: back. And our heroes are coming home. We are not there yet, but we have made real progress, and the last thing we should do is turn back now. Here is my plan for the next 4 years. Making education and training a national priority, building on our manufacturing goal, boosting American made energy, reducing the deficit responsibly by cutting where we can and by asking the wealthy to pay a little more and ending the War in Afganistan, so we can do some nation building 
here at home. That is the right path, so, read my plan, compare it to Governor Romney's and decide which is better for you. It's an honour to be your President and I'm asking for your vote, So, together, we can keep moving America forward” [19].

It is important to note at the outset that this speech begins with arguments: "new jobs", "rising values", "auto industry: back", "heroes coming home". Thus, summing up the evidence of his actions, Barack Obama then states: "we have made real progress." The following sentences contain information about the tasks the presidential candidate has put forward: "boosting energy", "ending the war in Afghanistan", "reducing the deficit". In addition, the pronouns "we" and "our" occur as elements of tactics of cooperation. The motivations of the advertisement also include the verbs used in the imperative mood: "read", "compare", "decide", and a token, which means moving forward: "moving forward." Consequently, with the help of the linguistic means used in sentences, the politician clearly defines certain tasks and commit himself to achieve them; motivates people to act and become one team to create a decent future for their country.

A fairly large impact on society is also realized through the usage of tactics of informing. This tactic is quite convenient, since it only provides the recipients with some facts, in which the politician should not even cover his thoughts. Such influence can be called mediated, but clear argumentation and its persuasiveness somehow motivate voters to take active action.

"I'm Hillary Clinton and I approve this message. (Showing photos) This was me in 1964. The fear of nuclear war that we had as children. I never thought our children would ever have to deal with that again and to see that coming forward in its election is really scary. Trump asked three times, three times: 'Why can't we use nuclear weapons. I want to be unpredictable' What safeguards are there to stop any President, who may not be stable from launching a nuclear attack” [20].

It can be observed that this advertisement also is the combination of accusation tactic of which is achieved in the sentences "Why can not we use nuclear weapons. I want to be unpredictable ". That is, Trump is accused of preference to the "nuclear weapons". In addition, the negative attitude to politics is also expressed with the help of the such lexical unit, as: "to stop", which actually becomes the No 1 issue for Hillary Clinton. The very tactics of informing is realized in the first part of the appeal. In the sentence "This was me in 1964. The fear of a nuclear war that we had as children" reported the real story of a woman who talks about a hard childhood and does not want such a life in fear of a nuclear war to her children. In fact, Hilary Clinton does not express her own position in this advertisement, but the information presented in, clearly outlines the direction of work and the goals she intends to follow and motivates people to work as a whole.

Conclusions. As a result of the studying of work of many researchers, there was a clear differentiation of the term "strategy", "impact" and"argumentation". From among a variety of different classifications, one was selected, for which examples of American advertising were studied.

Advertisement has also been proven to be one of the most effective means of impact on society. Bright pictures, touching stories, motivating speeches are always part of one or another impact tactic on the mind of a person. Moreover, advertising messages have demand in various spheres of life: commercial, educational, sports, etc. The sphere of politics is not an exception, but on the contrary - very illustrative example.

Various strategies of influence were considered in the work, as well as the tactics by which these strategies can be implemented. It was interesting to conclude that none of the advertisements is an embodiment of only one tactic. It is a combination of various ways of impact, which change the recipient's point of view, create certain associations, emotions and feelings.

During the study of American political advertising, various language tools and methods for their use were identified. So, it can be concluded that in advertisement for the implementation of a strategy lexical means are used more often.

It was also discovered how much information could be raised in different ways and how it can drastically change the course of the entire communication process. Political 
advertising is a matter for the group of professionals who know how to put this or that policy in a fairly favourable light and win the voters' affection.

It is reasonable to consider further research of the chosen topic. Further detailed studies of other linguistic means, both in American political advertising and in advertisements of other countries within the framework of political discourse, can also be considered perspective.

\section{РЕАЛІЗАЦІЯ СТРАТЕГІЙ АРГУМЕНТАТИВНОГО ВПЛИВУ В АМЕРИКАНСЬКІЙ ПОЛІТИЧНІЙ РЕКЛАМІ}

Чуланова Г.В., кандидат філологічних наук, дочент

ORCID ID: https://orcid.org/0000-0001-9961-0308

Сизоненко М. I., студентка

Сумський державний університет

Email: g.chulanova@gf.sumdu.edu.ua,syzonenko9711@gmail.com

Стаття розглядає стратегію як чітко визначений план дій для досягнення комунікативної мети в рамках політичного дискурсу. Детально вивчені основні елементи аргументації та впливу, їх функції, а також значення для учасників комунікації. Крім того, в результаті опрацювання робіт багатьох дослідників, які також вивчали ию тему було чітко розмежовано поняття "стратегія», «вплив» та «аргументація». Особлива увага приділена різним класифікаціям стратегій впливу, які зазначені у роботах відомих дослідників, а також тактикам їх реалізаиії. У прочесі дослідження виявлено, що яскраві картинки, зворушливі історії, мотивуючі промови завжди є частиною тієї чи іншої тактики впливу на свідомість людини, неважливо помічає вона це чи ні. Причому рекламні ролики мають попит у різних сферах життя суспільства: комериійній, освітній, спортивній $i$ т.д. Сфера політики не $\epsilon$ винятком, а навпаки досить ілюстративним прикладом. Реклама визначена як основний засіб аргументативного впливу на суспільство у політичній сфері життя. На матеріалі розглянутих роликів американської політичної реклами визначено основні мовні засоби, якими користуються політики для досягнення визначеної комунікативної мети. Особливо детально були досліджені приклади використання різних стратегій і тактик, та виділені засоби їх втілення. Отже, 3 поміж иілого ряду різноманітних класифікачій було виділено одну, за якою і були досліджені приклади американської реклами. На основі всіх отриманих результатів, та знайдених фактів під час проведеного дослідження були сформован власні висновки в рамках обраної теми. Важливим етапом роботи було також виділення перспектив подальших досліджень обраної теми у рамках політичного дискурсу. 3 власної ініціативи були зазначені перспективи більш детальних спостережень й у інших сферах жсття, які чинять не менший вплив на сучасне суспільство.

Ключові слова: стратегія, аргументація, вплив, політична реклама

\section{РЕАЛИЗАЦИЯ СТРАТЕГИЙ АРГУМЕНТАТИВНОГО ВЛИЯНИЯ В АМЕРИКАНСКОЙ} ПОЛИТИЧЕСКОЙ РЕКЛАМЕ

Чуланова Г.В., кандидат филологических наук, дочент ORCID ID: https://orcid.org/0000-0001-9961-0308

Сизоненко М.И., студентка

Сумский государственный университет

Email: g.chulanova@gf.sumdu.edu.ua,syzonenko9711@gmail.com

Статья рассматривает стратегию как четко определенный план действий достижения коммуникативной иели в политической рекламе. Детально изучены основные элементы аргументаиии и воздействия, их функции, а также значение для участников коммуникации. Особое внимание уделено различным классификациям стратегий влияния, которые указаны в работах лингвистов, а также тактикам их реализации. Исследованы различные яркие картинки, трогательные истории и мотивирующие речи, которые создают большой эффект на зрителя. Реклама определена как действенное средство аргументативном влияния на обшество в политической сфере жизни. На материале рассмотренных американских политических рекламных роликов определены основные языковые средства, которыми пользуются политики для достижения определенной цели. Среди целого ряда различных классификачий выделена одна, по которой собственно были исследованы отобранные примеры американской рекламы. Важным этапом работы было также выделение перспектив дальнейших исследований выбранной темь в рамках лингвистики и других наук. По собственной инициативе были отмечены перспективы более детального изучения влияния рекламы, действие которого не менее и в других сферах жизни общества.

Ключевые слова: стратегия, аргументация, влияние, политическая реклама.

\section{REFERENCES}

1. Saienko M. G. Strategiia pidpryiemstva. Ternopil : Ekonomichna dumka, 2006. 390 p.

2. Cambridge Dictionary. URL : https://dictionary.cambridge.org/ru/. - (acceesed 25.10.2018). 
3. Kovgun O. I. Strategiia pidpryiemstva. Lviv : Novyi Svit, 2007. 324 p.

4. Ivin A. A. Osnovy teorii argumentatsii. Moscow : VLADOS, 1997. 235 p.

5. Sidorenko E. V. Lichnostnoe vliianiie i protivostoianiie chuzhomu vliianiiu. Sankt-Petersburg : SPbGY, 1997. P. 125-141.

6. Zimbardo F., Liaipe M. Sotsialnoie vliianiie. Sankt-Petersburg : Piter, 2001. 448 p.

7. Issers O. S. Kommunikativnyie strategii I taktiki russkoi rechi. Moscow : Editorial, 2003. 284 p.

8. Michalskaia A. K. Russkii Sokrat : lektsii po sravnitelno-istoricheskoi ritorike. Moscow : Akademiia, 1996.192 p.

9. Aikaiomova A. Politychna reklama yak protses komunikatsii. Viche. 2011. № 6. P. 2-5.

10. Michaleva O. L. Politicheskii diskurs : Spetsifika manipuliativnogo vozdeistviia. Moscow : LIBROKOM, 2009. $256 \mathrm{p}$.

11. Lisovskii S. F. Politicheskaia reklama. Moscow : Marketing, 2000. 182 p.

12. Donald Trump Approved TV Ad : TWO AMERICAS: ECONOM. - URL: https://www.youtube.com/watch?v=9bEEeM qVkk (acceesed 1.10.18).

13. The Scariest Trump Video Ever. - URL: https://www.youtube.com/watch?v=Kcthwv46wAg (acceesed: 1.10.18).

14. Khizr Khan, father of a fallen Muslim American hero. - URL https://www.youtube.com/watch?v=ct C2aPi3KA (acceesed 5.10.18).

15. "How Do We Measure 'Greatness' In America?". - URL: https://www.realclearpolitics.com/video/2016/10/06/hillary_clinton_ad asks_how do_we measure greatness in america.html (acceesed 11.10.18).

16. Ronald Reagan Advertisement: "It's Morning Again in America". - URL https://www.youtube.com/watch?v=_fy-uhxiXcE (acceesed: 15.10.18).

17. Top 10 Political Ads of 2016. - URL: https://www.youtube.com/watch?v=Bp6IO1I7t3Q. (acceesed: 5.10.18)

18. Vote for President Johnson on November 3. The stake is too high for you to stay home". - URL : https://www.youtube.com/watch?v=Hln1Jw1IY5s (acceesed: 5.10.18).

19. Determination-Obama for America TV Ad. - URL: https://www.youtube.com/watch?v=uONGtgxHjYk (acceesed 1.10.18)

20. The Most Memorable Political Ads of the 2016 Election. - URL https://www.huffingtonpost.com/entry/political-ads-2016 us 5811fff4e4b064e1b4b0a700 - (acceesed 1.10.18).

\section{СПИСОК ВИКОРИСТАНИХ ДЖЕРЕЛ}

1. Саєнко М. Г. Стратегія підприємства: підручник / М. Г. Саєнко. - Тернопіль : Економічна думка, 2006. $-390 \mathrm{c}$.

2. Cambridge Dictionary [Електронний ресурс] - Режим доступу : https://dictionary.cambridge.org/ru/. (дата звернення: 25.10.2018)

3. Ковгун О. І. Стратегія підприємства : навч. посібник / О. І. Ковгун. - Львів : Новий Світ, 2007. - 324 с.

4. Ивин А. А. Основы теории аргументации : учебник / А. А. Ивин. - Москва : ВЛАДОС, 1997. - 235 с.

5. Сидоренко. Е. В. Личностное влияние и противостояние чужому влиянию / Е. В. Сидоренко. - СанктПетербург : СПбГУ, 1997. - С. 125-141.

6. Зимбардо Ф. Социальное влияние / Ф. Зимбардо, М. Ляйпе. - Санкт-Петербург : Питер, 2001. - 448 с.

7. Иссерс О. С. Коммуникативные стратеги и тактики русской речи / О. С. Иссерс. - Москва : Едиториал, 2003. - 284 c.

8. Михальская А. К. Русский Сократ : лекции по сравнительно-исторической риторике / А. К. Михальская. - Москва : Академия, 1996. - 192 с.

9. Акайомова А. Політична реклама як процес комунікації / А. Акайомова // Віче. - Вип. 6. - 2011. - С. 2-5.

10. Михалёва О. Л. Политический дискурс: Специфика манипулятивного воздействия / О. Л. Михалёва. Москва : ЛИБРОКОМ, 2009. - 256 с.

11. Лисовский С. Ф. Политическая реклама / С. Ф. Лисовский. - Москва : Маркетинг, 2000. - 182 с.

12. Donald Trump Approved TV Ad : TWO AMERICAS: ECONOMY [Електронний ресурс]. - Режим доступу : https://www.youtube.com/watch?v=9bEEeM_qVkk. - (дата звернення: 1.10.18).

13. The Scariest Trump Video Ever [Електронний pecypc]. - Режим доступу : https://www.youtube.com/watch?v=Kcthwv46wAg. - (дата звернення: 1.10.18).

14. Khizr Khan, father of a fallen Muslim American hero [Електронний ресурс]. - Режим доступу : https://www.youtube.com/watch?v=ct_C2aPi3KA. - (дата звернення: 5.10.18).

15. "How Do We Measure 'Greatness' In America?" [Електронний pecypc]. - Режим доступу: https://www.realclearpolitics.com/video/2016/10/06/hillary clinton ad asks how do we measure greatness in_america.html. - (дата звернення: 11.10.18).

16. Ronald Reagan Advertisement: "It's Morning Again in America" [Електронний ресурс]. - Режим доступу : https://www.youtube.com/watch?v= fy-uhxiXcE. - (дата звернення: 15.10.18).

17. Top 10 Political Ads of 2016 [Електронний ресурс]. - Режим доступу https://www.youtube.com/watch?v=Bp6IO1I7t3Q. - (дата звернення: 5.10.18).

18. Vote for President Johnson on November 3. The stake is too high for you to stay home" [Електронний pecypc]. - Режим доступу : https://www.youtube.com/watch?v=HlnlJw1IY5s. - (дата звернення: 5.10.18).

19. Determination-Obama for America TV Ad [Електронний pecypc]. - Режим доступу https://www.youtube.com/watch?v=uONGtgxHjYk. - (дата звернення: 1.10.18). 
20. The Most Memorable Political Ads Of The 2016 Election [Електронний ресурс]. - Режим доступу : https://www.huffingtonpost.com/entry/political-ads-2016 us 5811fff4e4b064e1b4b0a700. звернення: 1.10.18).

Received: 6 November, 2018 